\title{
SSynthesis
}

International Scientific Conference of IT and Business-Related Research

\section{NOVI KOMUNIKACIONI KANALI U PROCESU DIFUZIJE INOVACIJA}

\section{NEW COMMUNICATION CHANNELS IN THE PROCESS OF DIFFUSION OF INNOVATIONS}

\author{
Aleksandar Mihajlović, Jelena Gajić, Radmila Živković, Ivana Brdar, Milena Bokić \\ Univerzitet Singidunum, Danijelova 32, Beograd, Srbija
}

\begin{abstract}
Apstrakt:
Sticanje konkurentske prednosti u savremenom poslovanju podrazumeva postojanje novih ideja koje su inspirisane pažljivim posmatranjem aktuelnih trendova na tržištu. Strateško razvijanje inovacija dovodi do stvaranja superiornih performansi proizvoda i obezbeđuje dugoročnu konkurentsku prednost. Karakteristike inovacija uslovljavaju različite stepene i brzinu prihvatanja, a vreme prihvatanja inovacija je osnova uspešnog širenja na tržištu. Prosečno vreme za koje potrošač prihvata novi proizvod ukazuje na vremenski period koji će biti potreban da bi se nov proizvod široko prihvatio. Cilj rada je da ukaže na značaj komunikacionih kanala i definisanje strategije koje omogućavaju efikasno informisanje, tzv. difuziju inovacija kroz sofisticirano „ubeđivanje“ potrošača. Rezultati istraživanja ukazuju da rani prihvatioci koriste komunikacione kanale demonstrirajući putem njih jedinstvenu korist novih proizvoda i usluga.
\end{abstract}

\section{Ključne reči:}

rani prihvatioci, inovacije, komunikacioni kanali, društvene mreže.

\section{UVOD}

Inovacije predstavljaju imperativ današnjeg poslovanja, i postaju ključni faktor ne samo rasta, već i opstanka kompanija na tržištu. Uspeh kompanije, ogleda se u kontinuiranom stvaranju superiorne vrednosti za potrošače (korisnike usluga) i u pozicioniranju novog proizvoda/usluga na tržište pre konkurencije. Traganje za inovativnim načinima ostvarivanja tržišnog uspeha, uočljivo je na svim poljima poslovnog delovanja. Kompanije mogu biti inovatori ne samo stvarajući novi proizvod ili uslugu, već i stvarajući novi proizvodni ili uslužni proces, program lojalnosti, ili primenjujući nove načine organizovanja, tj. komunikacije. Inovacija za potrošača ne predstavlja samo nov proizvod, već i svaku drugu ideju koja se kako kvalitativno, tako i kvantitativno razlikuje od drugih i koju potencijalni kupac smatra novom (Milisavljević, 2003).

Nove tehnologije, internet, mobilni uređaji i celokupno savremeno informatičko okruženje u kojem živimo i poslujemo, doveli su do ogromnog povećavanja brzine komunikacije i stvaranja sveobuhvatnijeg globalnog tržišta. Zahvaljujući tome, uz pomoć savremenih tehnologija, društvenih mreža i internet poslovanja, kompanije danas brže i lakše komuniciraju sa svojim potrošačima, prikupljaju i obrađuju njihove podatke, otkrivaju njihove navike i prepoznaju njihove potrebe, čak i pre njih

\section{Abstract:}

Gaining a competitive advantage in the modern business world implies the existence of revolutionary ideas triggered by careful observation of the current market trends. Strategic innovation development leads to superior product performances and guarantees a long-term competitive advantage. The characteristics of innovations determine the degree and speed of their adoption, while the time of adoption is considered a prerequisite for successful expansion and positioning in the market. The average length of time that the consumer needs to adopt a new product indicates the total length of time that will be required for a new product to become widely adopted. The purpose of this paper is to indicate the importance of modern communication channels and define the strategy that would enable efficient provision of information, so-called diffusion of innovations by means of sophisticated consumer persuasion techniques. Research results indicate that early adopters use communication channels, thus demonstrating the unique benefits of new products and services.

\section{Key words:}

early adopters, innovations, communication channels, social networks.

samih. Okruženje u kome kolaboriraju kompanije i potrošači, omogućilo je kompanijama da postanu fleksibilnije i da brže reaguju na zahteve potrošača, a time sebi obezbede konkurentsku prednost.

Međusobna komunikacija potrošača kojima je stalo do nekog proizvoda ili usluge, obezbedila je jedan potpuno novi kanal koji je van opsega masovnog marketinga i prosečnih stvari. On ističe jedinstvenost, a danas, za kompanije, jedina sigurna stvar na tržištu je da budu izuzetne (Godin, 2005). Upravo takvo okruženje je rezultat kreativnosti i inovacija, a ujedno i generator novih ideja. Kreativnost predstavlja sposobnost generisanja i razvijanja novih ideja, a inovacije aktivnosti usmerene na stvaranje promena, pretvaranje ideja u realna i praktična rešenja, nove proizvode i jedinstvene usluge. Za kreativnost možemo reći da je neizostavan element inovacije, dok inovacije predstavlju zbir kreativnosti i uspešne implementacije. Uspešne inovacije su upravo one koje kvalitetnije i racionalnije mogu da odgovore na potrebe savremenih potrošača od prethodnih rešenja.

Inovacije su takođe i najbolje sredstvo za uspešno rešavanje velikih društvenih izazova, koji su svakim danom sve aktuelniji. Upravo zbog toga, Evropska komisija je označila inovacije kao jedan od najbitnijih faktora, kako za izlazak iz svetske ekonomske krize, tako i za rast evropske ekonomije (European Commision, 2011). 


\section{EVOLUCIJA INOVACIJA DIGITALNIH POTROŠAČA}

Inovacija je ideja, proizvod, odnosno usluga koja se, od strane pojedinca, doživljava i prihvata isključivo kao nova. Doživljaj nove ideje za pojedinca određuje njegova reakcija na nju. Ako je ideja nova, onda se ona smatra inovacijom (Rogers, 2003). Veoma često se prave semantičke greške, pa se ne pravi razlika između otkrića, ideje, pronalaska, izuma, invencije i inovacije (Roco \& Bainbridge, 2013). Inovacija je kompleksnija aktivnost, jer pored tehnologije obuhvata i marketing, finansiranje i druge ekonomske aktivnosti. Inovacija je deo, tj. faza inovacionog ciklusa (sl. 1) koji obuhvata jedinstven razvojni ciklus:

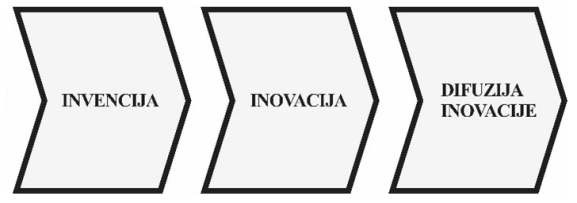

Slika 1. Razvojni ciklus

Izvor: Proven Models http://www.provenmodels.com/14

Takođe, inovacije možemo definisati kao prvu praktičnu primenu pronalaska ili naučnog otkrića. Najbrojnije i ekonomski najvažnije su tehnološke inovacije, koje imaju odlučujući uticaj na razvoj proizvodnje i privredu u celini, a predstvljaju prvo lansiranje novog proizvoda, novog ili bitno poboljšanog tehnološkog procesa. Jakšić et al. (2006) navode da o dubini inovativnosti one mogu biti fundamentalne (rezultat fundamentalnog i primenjenog istraživanja i razvojnog rada) ili funkcionalne, odnosno adaptivne (rezultat primenjenog istraživanja i/ili razvojnog rada).
Karakteristike inovacija uslovljavaju različite stepene i brzinu prihvatanja. Osnovne karakteristike inovacije su: „relativna prednost“ koja se ogleda u sagledavanju elemenata u kojima inovacija prednjači u odnosu na proizvode u istoj klasi, „kompatibilnost" koja prikazuje koliko su inovacije u skladu sa postojećim vrednostima, prošlim iskustvom ali i potrebama ranih prihvatioca, „kompleksnost“ koja predstavlja složenost inovacije za razumevanje i korišćenje, „eksperimentalnost“ koja se ogleda u relativnoj jednostavnosti testiranja inovacije pre donošenja odluke, „mogućnost posmatranja“ koja prikazuje koliko su rezultati inovacije vidljivi drugima (Rogers, 2003).

Dobar primer evolucije u inovacijama su mobilni telefoni, tačnije pametni telefoni čiji nastanak vezujemo za 1973. godinu. Zvanično su bili predstavljeni javnosti od strane kompanije Ericsson tek 1997. godine, a zatim od strane kompanije Nokia koja je dugi niz godina bila lider na tržištu mobilnih telefona. Tržište pametnih telefona je bilo „uzburkano“ plasiranjem prvog pametnog telefona kompanije Apple 2007. godine. Inovacije u ovoj kategoriji proizvoda su dovele do toga da od 2010. godine, tržište pametnih telefona postaje jedno od najbrže rastućih tržišta na svetu. O tome svedoče i rezultati onlajn istraživanja kompanije Accenture o životnom stilu digitalnih potrošača; $52 \%$ ispitanika planira da kupi pametne telefone u naredinih 12 meseci, dok samo 4\% trenutno nema ovaj telefon (sl. 2).

Prilikom planiranja kupovine digitalnih uređaja i dalje dominiraju multifunkcionalni uređaji, gde čak svaki peti potrošač planira da kupi još jedan pametni telefon, HD-TV, fablet ili tablet uređaj. Istraživanje je takođe utvrdilo da je više od $51 \%$ potrošača zainteresovano da kupi fablet uređaje, koji predstavljaju fuziju pametnih telefona i tableta, čija se veličina ekrana kreće u rasponu od 5 do 7 inča.

U prilog privlačnosti prema najnovijim inovacijama, potrošači nameravaju da ulože $33 \%$ više novčanih sredstava u uređaje, nego u prateće sadržaje i usluge. Samo 20\% ispitanika planira da poveća potrošnju na broadband internet usluge, 19\% na usluge mobilne telefonije, $13 \%$ na video i $12 \%$ na druge sadržaje (sl. 3 ).

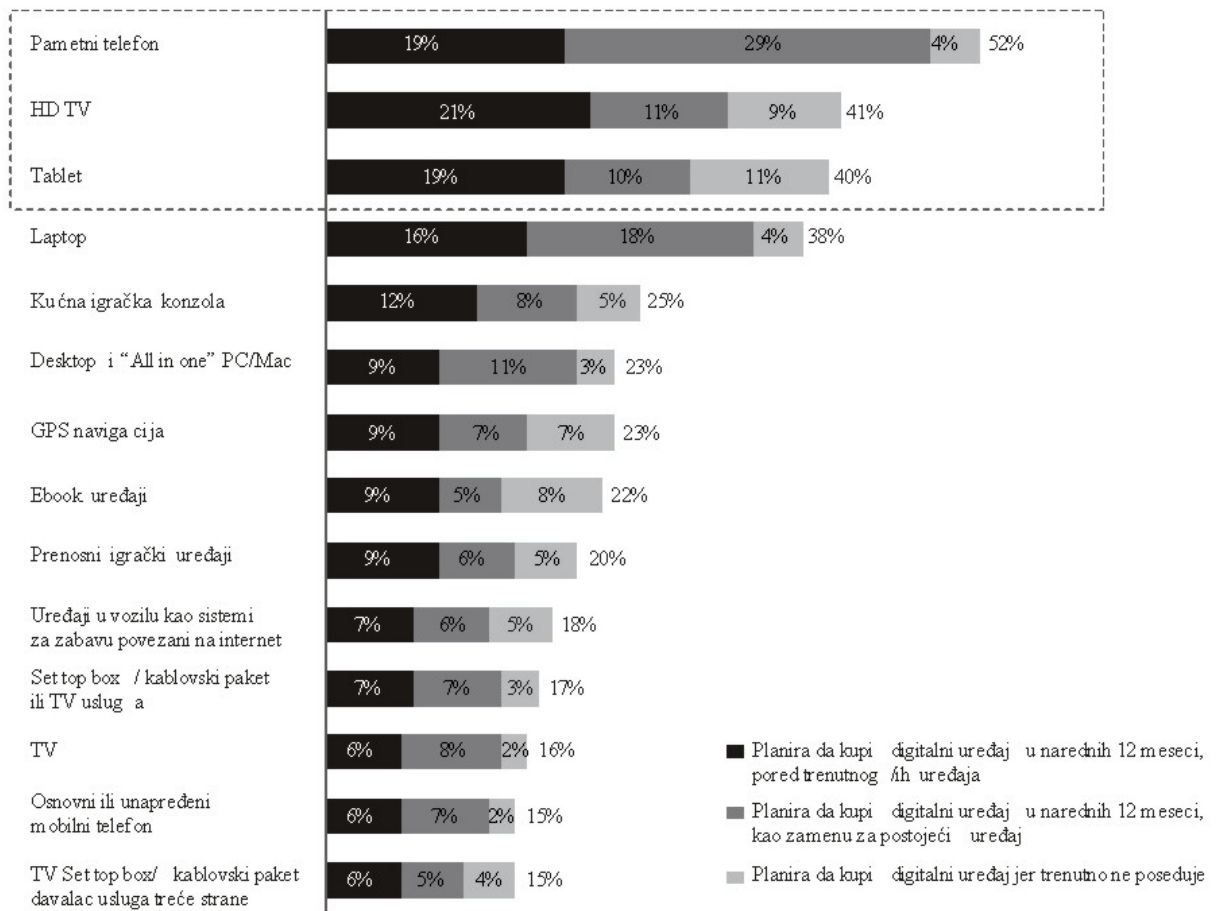


Koliko će se iznos koji planirate da potrošite, za digitalne usluge i uređaje navedene ispod, prome niti u narednih 12 meseci?

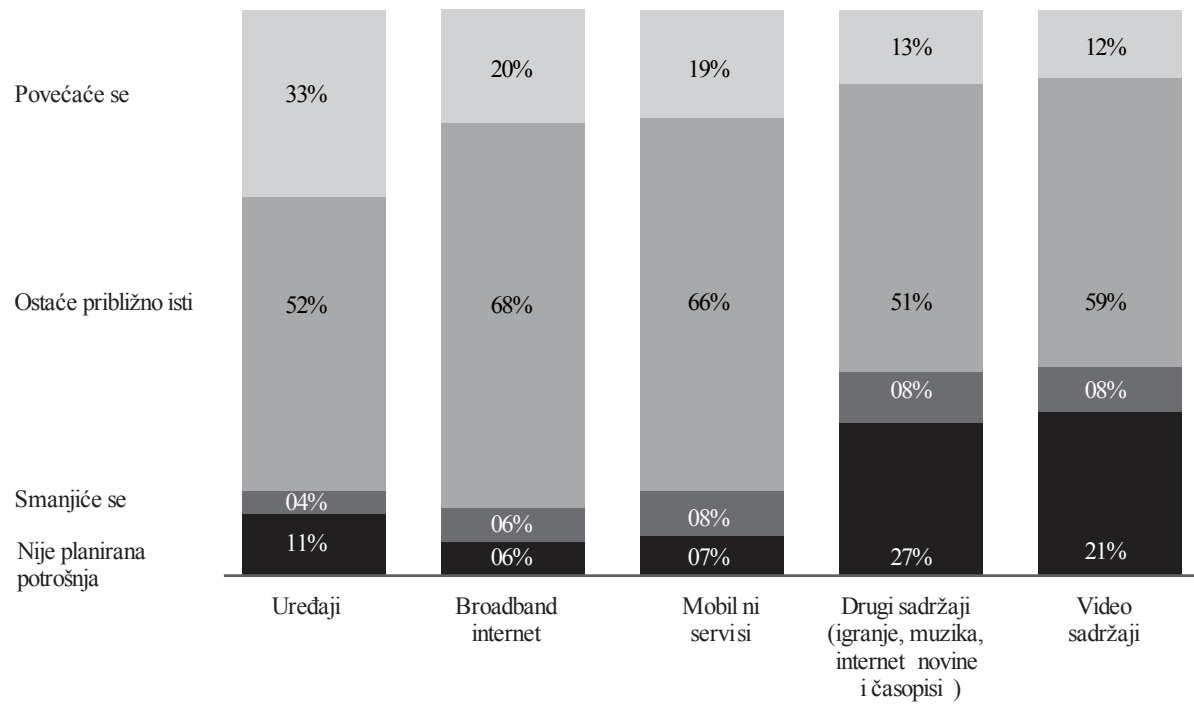

Slika 3. Namere o kupovini

Izvor: Accenture http://www.accenture.com/SiteCollectionDocuments/PDF/Accenture-Digital-Consumer-Tech-Survey-2014.pdf/

\section{DIFUZIJA INOVACIJE - PLANSKO ŠIRENJE IDEJA}

Difuzija predstavlja proces u kome se inovacija komunicira kroz odgovarajuće kanale između članova društva u određenom vremenskom periodu. Rogers (2003) ističe da postoje četiri ključne komponente difuzije (sl. 4): inovacija, kanali komunikacije, određeno vreme i članovi nekog društvenog sistema.

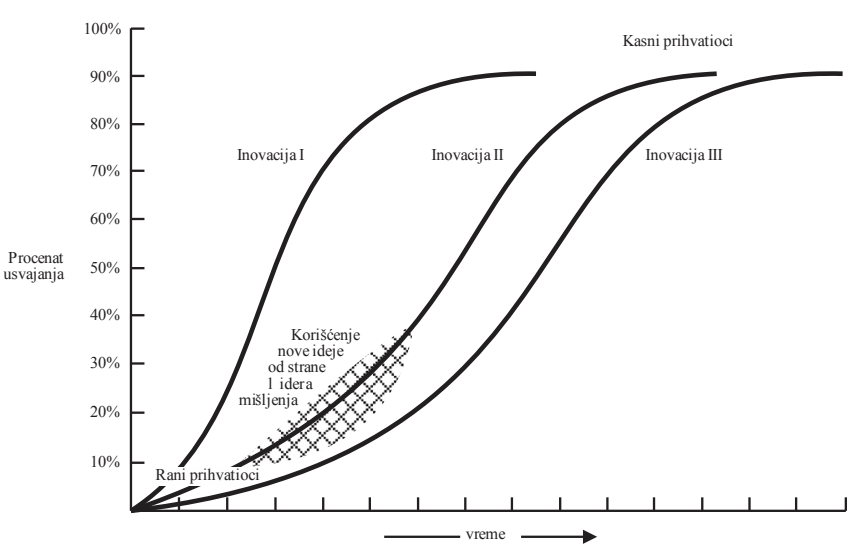

Slika 4. Četiri ključne komponente difuzije Izvor: Rogers, E.M. (2003).

Difuzija je specifičan tip komunikacije u kome su poruke kreirane oko nove ideje. Te nove ideje u sadržaju poruke daju difuziji njen specifičan karakter. Novost, novina znači da je neki stepen neizvesnosti uključen u difuziju. Difuziju neki autori vezuju za spontano, slučajno širenje ideja ali Rogers naglašava kako spontano tako i plansko širenje ideja (Rogers, 2003).

Upravljanje difuzijom inovacije, danas je posebno značajno za savremeno poslovanje, s obzirom da su mnoga istraživanja povezana sa tehnološkim inovacijama. Kotler et al. (2007) navode da način širenja inovacije sa aspekta vremena prihvatanja se najčešće deli u pet kategorija potrošača: inovatori, rani prihvatioci, rana većina, kasna većina i zakasneli (sl. 5).

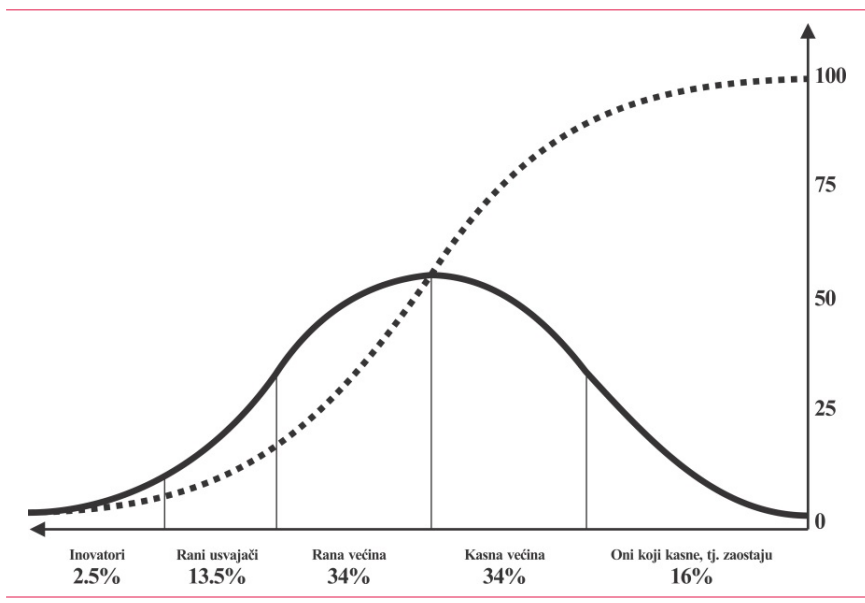

Slika 5. Kategorizacija usvojilaca na osnovu inovativnosti Izvor: Milisavljević, M. (2003).

Ove kategorije prihvatilaca novih proizvoda u dobroj meri se poklapaju i korespondiraju sa fazama u životnom ciklusu proizvoda: uvođenje, rast, zrelost i opadanje. Za uspeh inovacija su presudni rani prihvatioci ili „najbolji promoteri“ novih proizvoda i usluga.

\section{4. „LIDERI MIŠLJENJA“ - RANI PRIHVATIOCI}

Uloga društva, posebno inovatora i ranih privatioca, u širenju novih ideja i tehnologije istražuje se još od 60 -ih godina prošlog veka (Rogers, 2003). U ovom kontekstu najveći značaj imaju rani prihvatioci koji čine malu grupu ljudi koji „menjaju svet“. Oni se najćešće definišu kao radoznali, avanturistički potrošači koji prvi kupuju i brzo šire dobre ili loše "glasine“ o svom potrošačkom iskustvu. Međutim, potrebno je istaći da postoje i izuzeci koji vešto izbegavaju širenje novosti jer žele da izbegnu da ih drugi ljudi kopiraju.

Rani prihvatioci se tretiraju kao „lideri mišljenja“ koji su visoko obrazovani, imaju visoke prihode i imaju određeni društveni status. Njihova uloga je posebno značajna jer su oni društveno aktivni i ohrabruju druge potrošača da prihvate 
inovaciju. U digitalnoj eri, njihova uloga je još veća, posebno kada govorimo o uvođenju novih proizvoda/usluga na tržište (Rogers, 2003).

Rane prihvatioce od drugih korisnika posebno razlikuje vreme prihvatanja, što predstavlja osnovu procesa širenja inovacija. Vremenski period koji je potreban da se novi proizvod prihvati u širem obimu, je pod direktnim uticajem prosečnog vremena za koje potrošač prihvata inovaciju. Što je vreme od saznanja do kupovine novog proizvoda kraće, to će celokupna stopa širenja inovacije biti brža, i obrnuto. Najnovija istraživanja pokazuju da se poslednjih godina životni ciklus proizvoda znatno skratio, a da se istovremeno povećala brzina širenja inovacije. Glavne barijere u širenju inovacija predstavlja otpor potrošača prema inovacijama koje nisu u skladu sa njegovim ranijim verovanjima. Maričić (2011) razlikuje dve vrste potrošačkih barijera: funkcionalne (korišćenje, vrednost, rizik) i psihološke (tradicija, imidž), a one se mogu prevazići pravilnim izborom adekvatnog komunikacionog kanala i atraktivnog sadržaja poruke.

Kuo et al. (2013) navode da su osnovne karakteristike ranih prihvatilaca: fokusirani na tehnologiju, zagovornici revoluci- onarne promene, korisnici vizionari, orijentisani na projekte, spremni da preuzmu rizik, spremni da eksperimentišu, sami sebi dovoljni, i da teže horizontalnoj komunikaciji.

Prethodno navedeno potvrđuje istraživanje Accenture Digital Consumer Tech Survey (2014), koje pokazuje da su rani prihvatioci (više od 70\%) pokazali interesovanje za kupovinu funkcionalnih uređaja širokog spektra, od navigacije za vozila i uređaja za kućnu bezbednost, pa sve do uređaja za ličnu bezbednost i zdravlje i fitnes (sl. 6). Za ove potrošače nosiva tehnologija kristališe njihov kompletan digitalni životni stil.

Fromm et al. (2011) ističu da je, kad su inovacije u pitanju, potrebno razlikovati dve generacije sa suprotnim stavovima. Milenijumska generacija (rođeni između 1977. i 1995. godine) dva puta više želi da bude u ulozi ranih prihvatioca savremenih tehnologija nego starija, nemilenijumska generacija. Takođe, oko $26 \%$ ove generacije izvestilo je da su jedni od prvih ili među prvima koji su „probali“ nove tehnologije. Osim njih, 35\% je onih koji čekaju da prođe neko vreme pre nego što probaju nove tehnologije, odnosno $22 \%$ je onih koji su priznali da su čekali da tehnologija postane masovno prihvaćena (sl. 7).

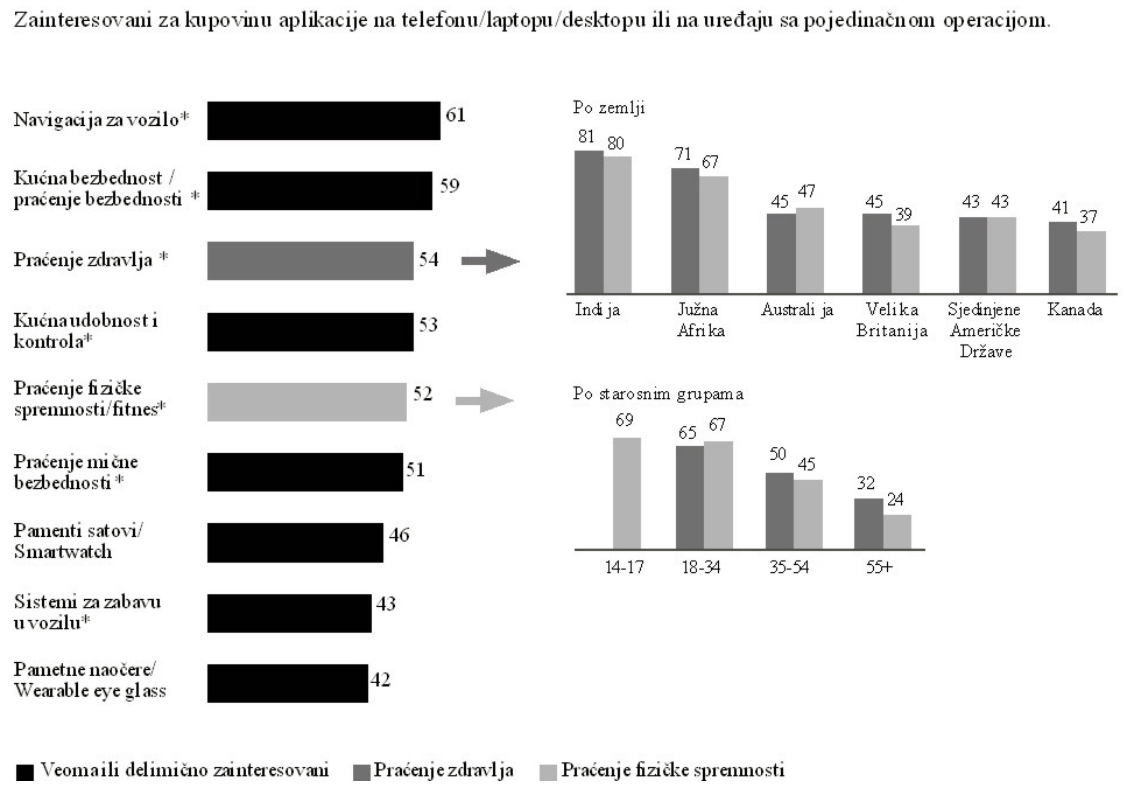

Slika 6. Interesovanje za digitalne ponude

Izvor: Accenture http://www.accenture.com/SiteCollectionDocuments/PDF/Accenture-Digital-Consumer-Tech-Survey-2014.pdf/

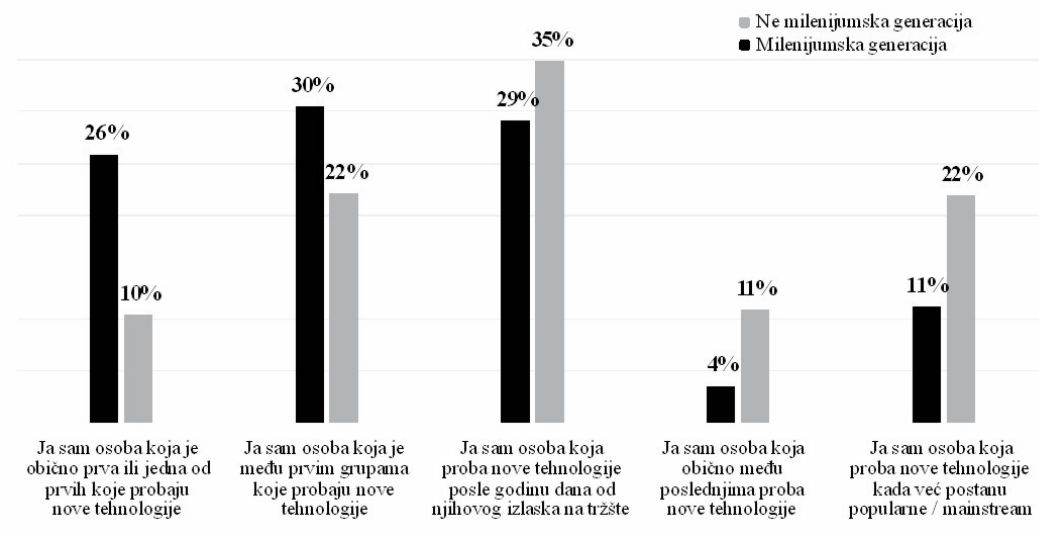




\section{ZNAČAJ KOMUNIKACIONIH KANALA I DRUŠTVENIH MREŽA U DIFUZIJI INOVACIJA}

Komunikacioni kanali su sredstva uz pomoć kojih se prenose informacije tj. poruke. Oni se menjaju i usavršavaju pod uticajem savremenih informacionih tehnologija. Postoje dve vrste komunikacionih kanala: masovni mediji i interpersonalni kanali. Masovni mediji su kanali koji putem radija, televizije, novina, itd., šalju poruku javnosti. Nasuprot tome, interpersonalni kanali su efektivniji u ubeđivanju da se nova ideja promoviše i prihvati, posebno kada se radi o ličnim kanalima koji povezuju dvoje ili više ljudi koji imaju sličan socioekonomski status, obrazovanje i sl. (Jobber \& Fahy, 2012). Interpersonalni kanali podrazumevaju razmenu licem u lice. Danas, bez obzira na tip kanala, komunikacija putem interneta je postala značajan izvor širenja inovacija. Ona je zadržala sve elemente ličnog kanala, bez potrebe direktnog prenošenja informacije, čime se sam proces prenosa informacija znatno ubrzao.

Komunikacione kanale takođe možemo kategorisati kao lokalne i globalne, koji komuniciraju između pojedinca iz određene društvene grupe i spoljnih izvora. Interpersonalni komunikacioni kanali mogu biti lokalni ili globalni, dok su skoro svi kanali masovnih medija globalni. Zbog ovih karakteristika globalni kanali i kanali masovnih medija imaju značajniju ulogu u fazama znanja, dok lokalni kanali i interpersonalni kanali imaju važniju ulogu u fazama ubeđivanja prilikom procesa donošenja odluka vezanih za inovacije (Sahin, 2006).

Internet je postao jedinstveno okruženje za pojavu i širenje inovacija, pružajući nove načine za komunikaciju. Istovremeno, promenio je poimanje osnovne interakcije dozvoljavajući pojedincu da deluje, nezavisno od njegove fizičke blizine (Montanaria \& Saberi, 2010). Kako je difuzija društveni proces koji podrazumeva interpersonalnu komunikaciju, omogućen je snažniji uticaj na kreiranje ili menjanje stavova pojedinaca. Jedan od najprepoznatljivijih problema u okviru difuzije inovacija je tendencija učesnika da se okupljaju u različite grupe, što je potpomognuto razvojem društvenih medija.

Društveni mediji se mogu definisati kao online platforme koje pojedinci koriste kako bi međusobno razmenili mišljenja i podelili svoja iskustva, uključujući fotografije, video snimke, muziku, itd. Platforme društvenih medija, mogu se kategorisati u osam glavnih celina: društvene mreže, blogovi, mikroblogovi, sajtovi sa deljenim sadržajima, sajtovi koji dozvoljavaju editovanje sadržaja i strukture od strane korisnika, centralizovani online servisi koji omogućavaju korisnicima da skladište i podelite bookmark-ove, podkastove i forume (Koçak et al., 2013).

Društvene mreže su danas postale savremeni način komunikacije. Intenzivna elektronska komunikacija utiče na brzo prenošenje iskustva i kreiranje pozitivnih i negativnih stavova. Osnovni značaj komercijalne upotrebe internet društvenih mreža ogleda se u njihovoj efikasnosti, efektivnosti, pristupačnosti i proaktivnom stavu.

Imajući u vidu da se veliki broj socijalnih i tehnoloških inovacija širi putem društvenih mreža, došlo je do brzog rasta i povećanja popularnosti u ovoj sferi internet interakcije između potrošača i kompanija. Zahvaljujući razvoju društvenih medija, rani prihvatioci imaju potencijal da ostvare još veći uticaj nad proizvodima koje kupuju i testiraju, posebno kada su u pitanju mali uređaji i onlajn brendovi. Prema navodima Forrester Research-a, čak 70\% odraslih koristi društvene mreže, blogove ili video (Advertising Age, 2010).

Međutim, iako je jedna od glavnih uloga ranih prihvatilaca da šire vesti i informacije o inovacijama, potrebno je napomenuti da oni često dođu u konflikt interesa u komuniciranju. Naime, rani prihvatioci imaju veliku potrebu da budu jedinstveni i iz tog razloga se hvale drugim ljudima, ali istovremeno, oni se često plaše da će na taj način podstaći druge da ih imitiraju i da će tako izgubiti svoju posebnost. Njihova želja da pričom promovišu inovaciju, koja je povezana sa njihovom tendencijom za ranim usvajanjem, je ujedno i ograničena željom da očuvaju svoj jedinstveni društveni status (Moldovan et al., 2015).

Centar za marketing istraživanja Univerziteta u Masačusetsu (University of Massachusetts Dartmouth) objavio je studiju o usvajanju društvenih medija među 500 najvećih američkih kompanija. Studija je proširena tokom godina, kako bi uključila korišćenje najbrže rastućih društvenih medijskih platformi i alata (Instagram, Google+, Foursquare i Pinterest), poslovne mrežne platforme (LinkedIn), kao i pokazatelje angažmana kao što su broj Facebook fanova i sledbenika na Twitter-u. U 2014. godini 157 preduzeća (31\%) je imalo korporativne blogove, što je za 3\% manje u odnosu na 2013. godinu. Najaktivnije su bile dve kompanije, Wal-Mart Stores i Exxon Mobil. Kada je u pitanju upotreba Twitter-a, zabeležen je porast od $6 \%$ u odnosu na 2013. godinu, kada je 413 kompanija (83\%) posedovalo korporativni nalog sa najmanje jednim tweet-om na mesečnom nivou. Kompanija Facebook, već drugu godinu za redom, ima najveći broj sledbenika na Twitter-u, a zatim slede Starbucks, Microsoft, Walt Disney Company, Whole Foods Market, Inc., Nike, Inc., i Intel Corporation. Facebook beleži najveći broj korisnika, gde od ukupno 500, čak 401 kompanija (80\%) svakodnevno koristi ovu društvenu mrežu, što je za $10 \%$ više u odnosu na 2013. godinu. Druge društvene mreže takođe su zabeležile rast. Foursquare je uživao najveći porast (42\%), dok je korišćenje Pinterest-a povećano za 27\%, a Instagrama za 12\% (Barnes \& Lescault, 2014).

\section{ZAKLJUČAK}

U dinamičnoj tržišnoj privredi, preduzeća na različite načine dolaze do novih proizvoda i uključuju ih u svoju marketing strategiju. Pojava tehnoloških inovacija omogućava promene na postojećim i uvođenje novih proizvoda, ostvarujući na taj način rast i opstanak preduzeća na tržištu. Odluke o novom proizvodu su odluke dugoročnog karaktera i od velikog značaja u tom procesu je razumevanje kako doći do superiorne vrednosti za potrošače. Potrošači se razlikuju u spremnosti ili želji da prihvate nešto novo što produžava proces difuzije inovacija. Pre više godina je ustanovljeno da postoje četiri kategorije prihvatioca novih proizvoda i rezultati istraživanja ukazuju da rani prihvatioci (oko 13,5\% od potencijalnog tržišta) su spremni da prihvate rizik i kupe nov proizvod. Prava priroda efekta uticaja društvenih mreža na difuziju inovacija, još uvek je nejasna, i u mnogim slučajevima, postoje konfliktne hipoteze među istraživačima.

\section{LITERATURA}

Accenture. (2014). Racing Toward a Complete Digital Lifestyle: Digital Consumers Crave More Accenture Digital Consumer Tech Survey 2014. Pristupljeno 07. marta 2015. na http:// www.accenture.com/SiteCollectionDocuments/PDF/ Accenture-Digital-Consumer-Tech-Survey-2014.pdf/

Advertising Age. (2010). Shiny new things. Pristupljeno 16. marta 2015. na http://adage.com/images/bin/pdf/shiny_new_ things.pdf

Barnes, N.G., \& Lescault, A.M. (2014). The 2014 Fortune 500 and Social Media: LinkedIn Dominates As Use of Newer Tools Explodes. Pristupljeno 02. marta 2015. na https://centerformarketingresearch.wordpress.com/2014/09/10/the2014-fortune-500-and-social-media-linkedin-dominatesas-use-of-newer-tools-explodes/ 
European Commission. (2011). Communication from the Commission to the European Parliament, the Council, the European Economic and Social Committee and the Committee of the Regions, A Single Market for Intellectual Property Rights Boosting creativity and innovation to provide economic growth, high quality jobs and first class products and services in Europe. Pristupljeno 07. februara 2015. na http:// ec.europa.eu/internal_market/copyright/docs/ipr_strategy/ COM_2011_287_en.pdf/

Fromm, J., Lindell, C., \& Decker, L. (2011). American Millennials: Deciphering the Enigma Generation, Kansas City: The Boston Consulting Group and Barkley.

Godin, S. (2005). Purple Cow. London: Penguin Books.

Jakšić, M., Backović, M., Cerović, B., \& Medojević, B. (2006). Ekonomski rečnik. Beograd: Centar za izdavačku delatnost Ekonomskog fakulteta u Beogradu.

Jobber, D., \& Fahy, J. (2012). Foundations of Marketing. London: McGraw-Hill.

Koçak, N.G., Kaya, S., \& Erol, E. (2013). Social Media from the Perspective of Diffusion of Innovation Approach. The Macrotheme Review, 2(3), 22-29. Pristupljeno 02. marta 2015. na http://macrotheme.com/yahoo_site_admin/ assets/docs/3KayaMR23.40131136.pdf

Kotler, P., Sonders, D., \& Armstrong, G. (2007). Principi marketinga. Beograd: Mate.

Kuo, L.H., Wei, H.M., Hu, W.C., \& Yang, H.J. (2013). Applying Innovation Theory in Observing Emerging Technology Acceptance, International Journal of Systems Applications, Engineering \& Development, 1(7) 56-65. Pristupljeno 02. marta 2015. na http://www.naun.org/main/UPress/ saed/2014-110.pdf
Lajović, D., \& Vulić, V. (2010). Tehnologija i inovacije - skripta. Podgorica: Ekonomski fakultet Podgorica.

Maričić, B. (2011). Ponašanje potrošača, Beograd: Centar za izdavačku delatnost Ekonomskog fakulteta u Beogradu.

Milisavljević, M. (2003). Marketing. Beograd: Savremena administracija.

Moldovan, S., Steinhart, Y., \& Ofen, S. (2015). "Share and scare": Solving the communication dilemma of early adopters with a high need for uniqueness. Journal of Consumer Psychology, 25(1), 1-14. DOI: 10.1016/j.jcps.2014.06.001

Montanaria, A., \& Saberib, A. (2010). The Spread of Innovations in Social Networks. Proceedings of the National Academy of Sciences of United States of America, 107(47), 20196-20201. DOI: 10.1073/pnas.1004098107

Proven Models. Invention innovation diffusion trilogy. Pristupljeno 27. februara 2015. na http://www.provenmodels. com $/ 14$

Roco, M.C., \& Bainbridge, W.S. (2013). The new world of discovery, invention, and innovation:convergence of knowledge, technology, and society. Journal of Nanoparticle Research, 15(1946), 2-17. DOI: 10.1007/s11051-013-1946-1

Rogers, E.M. (2003). Diffusion of innovation. New York: The Free Press.

Sahin, I. (2006). Detailed Review of Rogers' Diffusion of Innovations Theory and Educational Technology-Related Studies Based on Rogers' theory. The Turkish Online Journal of Educational Technology - TOJET, 5(2), 14-23. Pristupljeno 27. februara 2015. na http://www.tojet.net/articles/ v5i2/523.pdf 